17 days from its onset. Twelve out of the 17 patients studied still had Eaton C.F. antibodies five months later.

The incidence of Eaton pneumonia in 102 cases with cold agglutinins in titre $\geqslant 32$ was $26 \%$ and in 144 pneumonias without cold agglutinins $9 \%$. Conversely, $68 \%$ of the Eaton pneumonias and $36 \%$ of non-Eaton pneumonias were coldagglutinin-positive.

In two control groups, comprising 484 blood donors and 118 surgical patients aged under 16 years, Eaton antibodies in titre $\geqslant 8$ were found in 5.4 and $32 \%$. The corresponding figures for the same age-groups in the pneumonia series were 31 and $52 \%$. These differences found between the pneumonia group and the control series were highly significant. None of the blood donors and only two of the surgical patients had an Eaton PPLO C.F. titre of 32.

It is to be hoped that the results obtained by studying the Eaton PPLO C.F. antibodies in patients with pneumonia will stimulate the investigation of the role of PPLO in other human diseases. The C.F. technique provides a simple method.

We wish to express our gratitude to Professor Thomas Anderson, Glasgow, for his criticism and valuable advice and for correcting the manuscript. We wish to thank Dr. Harri Nevanlinna, head of the Finnish Red Cross Blood Bank, for the blood donors' samples. We are also grateful to Dr. G. R. Wallgren, assistant head of the Children's Surgical Department of Aurora Hospital, for blood samples from surgical cases.
One of us (E. J.) had the opportunity in October 1962 in London of meeting Dr. E. Klieneberger-Nobel and Dr. R. Lemcke (Lister Institute) and discussing their PPLO methods. Dr. L. Hayflick (Wistar Institute, Philadelphia) was kind enough to send us the Eaton PPLO strain. We wish to express our sincere thanks to these three doctors.

\section{REFERENCES}

Chanock, R. M. (1962). 7. Hyg. Epidem. (Praha), 6, 59.

Cook, M. K., Fox, H. H., Parrott, R. H., and Huebner, R. J. (1960). New Engl. f. Med., 262, 648.

- Hayflick, L., and Barile, M. F. (1962a). Proc. nat. Acad. Sci. (Wash.), 48, 41 .

James, W. D., Fox, H. H., Turner, H. C., Mufson, M. A., and Hayflick, L. (1962b). Proc. Soc. exp. Biol. (N.Y.), 110, 884.

Mufson, M. A., Bloom, H. H., James, W. D., Fox, H. H., and Kingston, J. R. (1961a). F. Amer. med. Ass., 175, 213.

- Rifkind, D., Kravetz, H. M., Knight, V., and Johnson, K. M. (1961b). Proc. nat. Acad. Sci. (Wash.), 47, 887.

Cook, M. K., Chanock, R. M., Fox, H. H., Huebner, R. J., Buescher, E. L., and Johnson, R. T. (1960). Brit. med. F., 1, 905.

Evans, A. S., and Brobst, M. (1961). New Engl. F. Med., 265, 401.

Feller, A. E., and Hilleman, M. R..(1956). Diagnostic Procedures for Virus and Rickettsial Diseases. American Public Health Association, New York.

Jansson, E. (1960). Ann. Med. exp. Fenn., 38, Suppl. No. 4, p. 18. and Wager, O. (1961). Ann. Med. in:ern. Fenn., 50, 221.

Kingston, J. R., Chanock, R. M., Mufson, M. A., Hellman. L. P., James, W. D., Fox, H. H., Manko, M. A., and Boyers, J. (1961). f. Amer. med. Ass., 176, 118.

Liu, C., Eaton, M. D., and Heyl, J. T. (1959). F. exp. Med., 109, 545.

Mufson, M. A., Manko, M. A., Kingston, J. R., and Chanock, R. M. (1961). F. Amer. med. Ass., 178, 369.

\title{
Sensitivities of Colonies and Suspensions of Actinomyces Israelii to Penicillins, Tetracyclines, and Erythromycin
}

\author{
G. C. BLAKE,* M.B., B.S., F.D.s. R.C.S.
}

Brit. med. F., 1964, 1, 145-148

The usual method of assessing antibiotic sensitivity of Actinomyces israelii is the inoculation of serial dilutions of the antibiotic in liquid or semi-solid media with suspensions of $A$. israelii prepared from a pure culture. The inoculated tubes are incubated at $37^{\circ} \mathrm{C}$., if necessary in an anaerobic atmosphere, until a no-growth level can be determined. Because of the slow growth of the organism, a minimum period of five days' incubation is usually required.

During the period of culture the activity of the antibiotic in the media may fall considerably. In one experiment with benzylpenicillin in a medium of brain-heart infusion in sloppy agar, incubated at $37^{\circ} \mathrm{C}$., the penicillin activity (assessed by inhibition of a penicillin-sensitive staphylococcus) fell by more than $75 \%$ in five days (Fig. 1). With antibiotics which are labile in solution, therefore, organisms whose growth may have been inhibited during the first 24 hours of culture, but which remain viable, may begin to grow as the antibiotic activity falls, so that growth is eventually observed in tubes in which the true antibiotic concentrations are much below the original values. Minimum inhibitory concentrations found in this way are likely to be too high and may in some cases approach bactericidal levels.

A further difficulty in antibiotic testing of $A$. israelii arises from the apparent resistance to antibiotics of colonial masses of the organism (Holm, 1948). Because of this resistance the

- Institute of Dental Surgery (University of London), Eastman Dental Hospital. particle size of the suspension may affect the minimum inhibitory concentration (M.I.C.) found, and it is necessary to prepare fine homogeneous suspensions of the organism if accurate and constantly reproducible results are to be obtained.

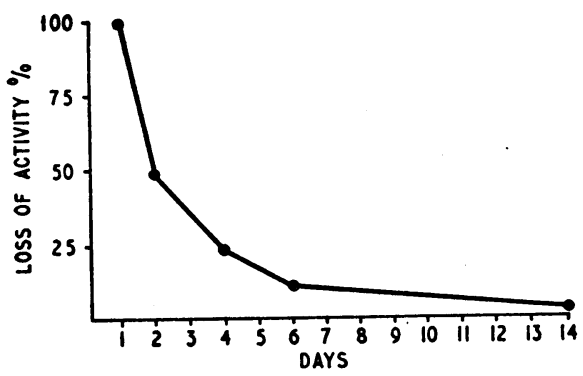

FIG. 1.-Loss of activity of benzylpenicillin in brain-heart infusion sloppy agar medium at $37^{\circ}$ C. The assessment was calculated from minimum inhibitory concentrations against a minimum inhibitory concentrations against a sensitive staphylococcus, after 24 hours' incuba-
tion in each sample. The first reading, 24 hours tion in each sample. The first reading, 24 hours $0.06 \mu \mathrm{g} . / \mathrm{ml}$. and is taken as $100 \%$ on the graph.

Different methods of preparing the suspensions have been employed by various workers, and the methods used may affect the result of the experiment. When suspensions of $A$. israelii (National Collection of Type Cultures (N.C.T.C.) No. 10236) were prepared by crushing the mycelial masses with a glass rod, 
the M.I.C. of benzylpenicillin found after five days' incubation was $0.03 \mu \mathrm{g} . / \mathrm{ml}$. ; the apparent M.I.C., however, increased to $0.25 \mu \mathrm{g} . / \mathrm{ml}$. at 10 days and $1 \mu \mathrm{g} . / \mathrm{ml}$. at 21 days. However, when the suspension was prepared by shaking the culture of the same organism with glass beads until no particles were visible to the naked eye, the M.I.C. was $0.015 \mu \mathrm{g} . / \mathrm{ml}$., increasing to $0.03 \mu \mathrm{g} . / \mathrm{ml}$. by eight days, which level remained constant for 21 days. The influence of particle size on inhibitory concentrations of antibiotics has been noted by others (Holm, 1948 ; Garrod, 1952).

It was thought that these difficulties in finding a true M.I.C. of antibiotics for $A$. israelii might be overcome by observing the effect of antibiotics on the growth of whole colonies over a short period. Holm (1948) described the seeding of colonies from blood-agar plates into liquid media containing serial dilutions of penicillin, and a similar method has been employed to obtain colonies for observations in the present investigation.

In his experiments Holm observed marked resistance to penicillin of actinomyces colonies from some strains. However, his results were obtained after prolonged culture, and it is probable that the results represented bactericidal rather than bacteriostatic levels of penicillin on the actinomyces colonies. In the present experiments it was found that an increase in the size of colonies could be observed with a low-power microscope in 18 hours, and that inhibitory concentrations of antibiotic could be determined before there had been any significant loss of antibiotic activity (Fig. 2). Experiments have been undertaken to find M.I.C.s of benzylpenicillin, phenoxymethylpenicillin, phenethicillin, methicillin, cloxacillin, ampicillin, erythromycin, tetracycline, and demethylchlortetracycline acting on the whole colonies of five strains of $A$. israelii for 18 and 72 hours. The experiments were extended to find bactericidal concentrations of the various antibiotics acting on whole colonies for 72 hours, and the relationship of M.I.C. for whole colonies to M.I.C. found by the suspension method has also been studied.



Fig. 2.-A. israelii colonies on blood agar in brain-heart infusion sloppy agar tubee with dilutions of benzylpenicillin. Bottom row: Control tube. Middle row: Highest penicillin concen ration before inhibition. Top row : M.I.C. of penicillin. ( $\times 3$.)

\section{Materials and Methods}

Cultures used in the experiments were all from cases of cervicn-facial actinomycosis; four were N.C.T.C. Nos. 4860,
10236, 10215, and 9756, and one was from a patient at the Eastman Dental Hospital, No. C/862/62. Colonies for the tests were obtained from cultures of the organism on bloodagar plates, subcultured from brain-heart infusion sloppy agar, and incubated anaerobically at $37^{\circ} \mathrm{C}$. for seven days. The plates were inoculated heavily enough to give discrete colonies close together, so that a piece of agar approximately 5 by $5 \mathrm{~mm}$. cut from the plate would carry many separate colonies.

Colonies on the agar squares were placed in serial doubled dilutions of the antibiotics in brain-heart infusion (Oxoid) in sloppy agar (from 0.0008 to $128 \mu \mathrm{g} . / \mathrm{ml} .\left(\log _{2}-10\right.$ to $\left.\log _{2} 7\right)$ ). The experiments were performed in $\frac{5}{8}$-in. $(1.6 \mathrm{~cm}$.) test-tubes 6 in. $(15 \mathrm{~cm}$.) long, each containing $10 \mathrm{ml}$. of medium. The squares of agar with colonies attached were placed 1 to $2 \mathrm{~cm}$. from the surface of the medium and positioned so that they could easily be observed with a plate microscope placed horizontally. After the agar squares carrying the colonies were in the tubes, the surfaces of the medium were layered with sterile liquid paraffin. The medium, when prepared, was at $\mathrm{pH}$ 7.4, which did not alter throughout the experiments. The dilutions of the antibiotics in the medium were made in bulk for the series of experiments with each antibiotic and then distributed to the test-tubes. Each parallel series of experiments included a control sensitivity determination with a sensitive staphylococcus.

Determination of Bacteriostatic Concentration for Colonies.In a preliminary series of experiments serial doubled dilutions of benzylpenicillin in brain-heart infusion sloppy agar were prepared from 0.0008 to $1 \mu \mathrm{g}$. $/ \mathrm{ml}$. The colonies were placed in the tubes, as described above, and were examined and photographed with a low-power microscope immediately they were in the medium. It was found, by examination of enlarged photographs of the colonies at 18 hours, that the inhibitory concentrations could be obtained ; by 72 hours the M.I.C. could be read with the naked eye (Fig. 2). As the readings remained constant between 18 and 72 hours, naked-eye observations at 72 hours were subsequently relied on.

Determination of Bactericidal Concentration for Colonies. In order to determine the bactericidal concentrations of antibiotics acting on colonies for 72 hours, the blood-agar squares with the colonies attached were removed from the antibiotic medium after 72 hours and placed in similar tubes of medium without antibiotic. To ensure that no antibiotic was carried over with the colonies, they were transferred a second time to antibiotic-free medium 24 hours later. The colonies were retained in the antibiotic-free medium at $37^{\circ} \mathrm{C}$. for 21 days. Examination of the tubes for colony growth was made daily. Colonies which had not grown in 21 days were subcultured on to blood-agar plates and retained for a further 21 days in an anaerobic atmosphere at $37^{\circ} \mathrm{C}$. Colonies which had not grown in this time were recorded as dead.

Determination of Bacteriostatic Concentration for Suspensions.-The suspensions were all from cultures in brain-heart infusion sloppy agar incubated for seven days at $37^{\circ} \mathrm{C}$. Particles of the growth were drawn from the media with Pasteur pipettes into $15 \mathrm{ml}$. of broth. The broth was then shaken with glass beads until no visible particles remained. There was no measurement of the amount of culture used in each experiment, but the quantity was kept as constant as possible in the different suspensions made. Each culture tube was inoculated with two drops of this suspension, the tubes being well shaken and layered with paraffin.

\section{Results}

M.I.C. for Colonies.-The minimum concentrations of each antibiotic which inhibited growth of the seven-day colonies of $A$. israelii read after 72 hours are shown in Table I (A), expressed on a $\log _{2}$ scale. The lowest levels at which inhibition occurred were obtained with benzylpenicillin, which inhibited colony growth of all five cultures at concentrations between 0.0035 and $0.015 \mu \mathrm{g} . / \mathrm{ml}$. In most experiments phenoxymethyl- 
TABLE I.-Antibiotic Sensitivities of Colonies and Suspensions of Actinomyces Israelii

\begin{tabular}{|c|c|c|c|c|c|c|c|c|c|c|}
\hline & Strain & $\begin{array}{l}\text { Benzyl- } \\
\text { penicillin }\end{array}$ & $\begin{array}{c}\text { Phenoxymethyl- } \\
\text { penicillin }\end{array}$ & $\begin{array}{l}\text { Phenethi- } \\
\text { cillin }\end{array}$ & $\begin{array}{l}\text { Ampi- } \\
\text { cillin }\end{array}$ & $\begin{array}{l}\text { Cloxa- } \\
\text { cillin }\end{array}$ & $\begin{array}{l}\text { Methi- } \\
\text { cillin }\end{array}$ & $\begin{array}{l}\text { Erythro- } \\
\text { mycin }\end{array}$ & $\begin{array}{l}\text { Tetra- } \\
\text { cycline }\end{array}$ & $\begin{array}{l}\text { Demethylchlor- } \\
\text { tetracycline }\end{array}$ \\
\hline $\begin{array}{l}\text { (A) M.I.C. for colonies, } \\
\text { at } 3 \text { days }\end{array}$ & $\begin{array}{l}\mathbf{A} \\
\mathbf{B} \\
\mathbf{C} \\
\mathbf{D} \\
\mathbf{E}\end{array}$ & $\begin{array}{l}-6 \\
-8 \\
-6 \\
-8 \\
-6\end{array}$ & $\begin{array}{l}-5 \\
-6 \\
-6 \\
-6 \\
-5\end{array}$ & $\begin{array}{l}-5 \\
-5 \\
-4 \\
-7 \\
-5\end{array}$ & $\begin{array}{l}-5 \\
-5 \\
-8 \\
-6 \\
-5\end{array}$ & $\begin{array}{l}-2 \\
-2 \\
-3 \\
-3 \\
-3\end{array}$ & $\begin{array}{l}0 \\
1 \\
2 \\
1 \\
1\end{array}$ & $\begin{array}{l}-5 \\
-5 \\
-4 \\
-3 \\
-6\end{array}$ & $\begin{array}{l}-1 \\
-1 \\
-1 \\
-2 \\
0\end{array}$ & $\begin{array}{l}-2 \\
-3 \\
-3 \\
-4 \\
-2\end{array}$ \\
\hline $\begin{array}{l}\text { (B) M.I.C. for suspen- } \\
\text { sions, at } 5,10 \text {, and } 21 \\
\text { days }\end{array}$ & $\begin{array}{l}\mathbf{A} \\
\mathbf{B} \\
\mathbf{C} \\
\underset{\mathbf{D}}{\mathbf{D}}\end{array}$ & $\begin{array}{l}-6-5-4 \\
-6-5-4 \\
-6-5-5 \\
-6-6-5 \\
-6-5-4\end{array}$ & $\begin{array}{l}-3-3-3 \\
-5-5-5 \\
-7-4-4 \\
-7-6-6 \\
-5-4-3\end{array}$ & $\begin{array}{l}-4-3-3 \\
-6-5-4 \\
-5-4-4 \\
-5-4-3 \\
-5-4-4\end{array}$ & $\begin{array}{l}-4-4-2 \\
-5-5-3 \\
-6-3-3 \\
-6-4-3 \\
-5-3-3\end{array}$ & $\begin{array}{l}-2-1+2 \\
-2-2-2 \\
-2-3-3 \\
-3-2-1 \\
-2-2+1\end{array}$ & $\begin{array}{lll}3 & 3 & 3 \\
2 & 2 & 2 \\
2 & 2 & 2 \\
0 & 1 & 2 \\
2 & 2 & 3\end{array}$ & $\begin{array}{l}-7-6-5 \\
-4-3-3 \\
-4-3-3 \\
-4-3-3 \\
-6-5-4\end{array}$ & $\begin{array}{rrr}0 & 1 & 2 \\
0 & 0 & 1 \\
-1 & 0 & 0 \\
-1 & 0 & 1 \\
-1 & 0 & 2\end{array}$ & $\begin{array}{rrr}0 & 0 & 1 \\
-1 & 0 & 0 \\
-2 & -2 & 0 \\
-1 & 0 & 0 \\
-1 & 0 & 1\end{array}$ \\
\hline $\begin{array}{l}\text { (C) Minimum bacteri- } \\
\text { cidal concentration for } \\
\text { colonies, after } 72 \text { hours' } \\
\text { exposure to antibiotics }\end{array}$ & $\begin{array}{l}\mathbf{A} \\
\mathbf{B} \\
\mathbf{C} \\
\mathbf{D} \\
\mathbf{E}\end{array}$ & $\begin{array}{l}6 \\
6 \\
0 \\
7+ \\
7+\end{array}$ & $\begin{array}{l}7 \\
2 \\
3 \\
7+ \\
7+\end{array}$ & $\begin{array}{l}2 \\
5 \\
7+ \\
7+ \\
6\end{array}$ & $\begin{array}{l}7 \\
7+ \\
7+ \\
7+ \\
7+\end{array}$ & $\begin{array}{l}4 \\
7+ \\
7 \\
7+ \\
7+\end{array}$ & $\begin{array}{l}7+ \\
4 \\
7+ \\
5 \\
7\end{array}$ & $\begin{array}{l}7+ \\
5 \\
5 \\
7 \\
5\end{array}+$ & $\begin{array}{l}\mathbf{7}+ \\
\mathbf{7}+ \\
\mathbf{7} \\
\mathbf{7} \\
\mathbf{7}+\end{array}$ & $\begin{array}{l}7+ \\
7+ \\
6 \\
7 \\
7+\end{array}$ \\
\hline
\end{tabular}

Strains : A, NCTC 4860 ; B, NCTC 10236 ; C, NCTC 10215 ; D, NCTC 9756 ; E, E.D.H. C/862/62.

The figures indicate the concentrations of the antibiotics expressed on a $\log _{2}$ scale. $-8=0.0035 \mu \mathrm{g} . / \mathrm{ml} . ;-7=0.007 ;-6=0.015 ;-5=0.03 ;-4=0.06 ;-3=0.125 ;$ $-2=0.25 ;-1=0.5 ; 0=1 ; 1=2 ; 2=4 ; 3=8 ; 4=16 ; 5=32 ; 6=64 ; 7=128$.

penicillin, phenethicillin, and ampicillin all inhibited colony growth at a concentration of $0.03 \mu \mathrm{g} . / \mathrm{ml}$. Cloxacillin most often gave an M.I.C. 16 times that of benzylpenicillin, while methicillin required a concentration approximately 128 times that of benzylpenicillin. Of the non-penicillin antibiotics tested erythromycin inhibited colony growth at levels similar to those found for phenoxymethylpenicillin, phenethicillin, and ampicillin, while tetracycline required a concentration 16 times as great. Demethylchlortetracycline inhibited growth of colonies of all five strains at concentrations approximately half those required for tetracycline.

M.I.C. for Suspensions.-The M.I.C.s of antibiotics tested by the suspension method are shown in Table I (B). The results were read at 5, 10, and 21 days. The results after five days' incubation accord well with those found by the whole-colony method. The five-day values were never lower than those found by the colony method and were most often double. The 10 - and 21-day readings gave apparent M.I.C.s two to four times those found at five days. With antibiotics which are labile in solution, only the five-day readings may be considered as true bacteriostatic concentrations. By 21 days, when the apparent inhibitory concentrations have become constant, it may be assumed that bactericidal concentrations of each antibiotic are being observed.

Bactericidal Concentration for Colonies.-Table I (C) shows the minimum bactericidal concentrations of the antibiotics acting for 72 hours on colonies of each of the strains tested. The highest concentration of antibiotic used was $128 \mu \mathrm{g} . / \mathrm{ml}$. $\left(\log _{2} 7\right)$. Colonies which were shown to be viable at this concentration are marked $7+$ in the table. In these experiments many colonies present on the agar did not grow and there was. a marked reduction in the number of viable colonies as the concentrations of the antibiotics increased. If any colonies remained viable at any concentration of antibiotic they are recorded as positive in Table II. There was an irregular pattern of bactericidal effect with some of the penicillins (Table II), especially marked above concentrations of $0.125 \mu \mathrm{g} . / \mathrm{ml}$. with benzylpenicillin, phenoxymethylpenicillin, and phenethicillin. The greatest bactericidal effects were shown by benzylpenicillin, phenoxymethylpenicillin, phenethicillin, methicillin, and erythromycin. No clear pattern of strain variation emerged.

\section{Discussion}

Minimum inhibitory concentrations of benzylpenicillin, erythromycin, and tetracycline, from the work of previous investigators, have been summarized by Garrod and Scowen (1960). The minimum concentration which inhibited colony growth in the experiments described in this paper are in general one-quarter of previously published M.I.C.s for the organism, and the M.I.C.s by the suspension method are in general half the previously published values.

It is suggested that the M.I.C.s found for whole colonies represent the true M.I.C. for this organism, and that the higher values obtained by the suspension method are due to the fall of antibiotic activity which takes place in unstable antibiotic solutions before there has been sufficient growth to obtain a definite reading. It is also suggested that the larger the particle size in the suspension the higher will be the apparent M.I.C. found. In our experiments the generally lower values found

TABLE II.-Colonies Viable After 21 Days Following 72 Hours' Exposure to Dilutions of Antibiotics

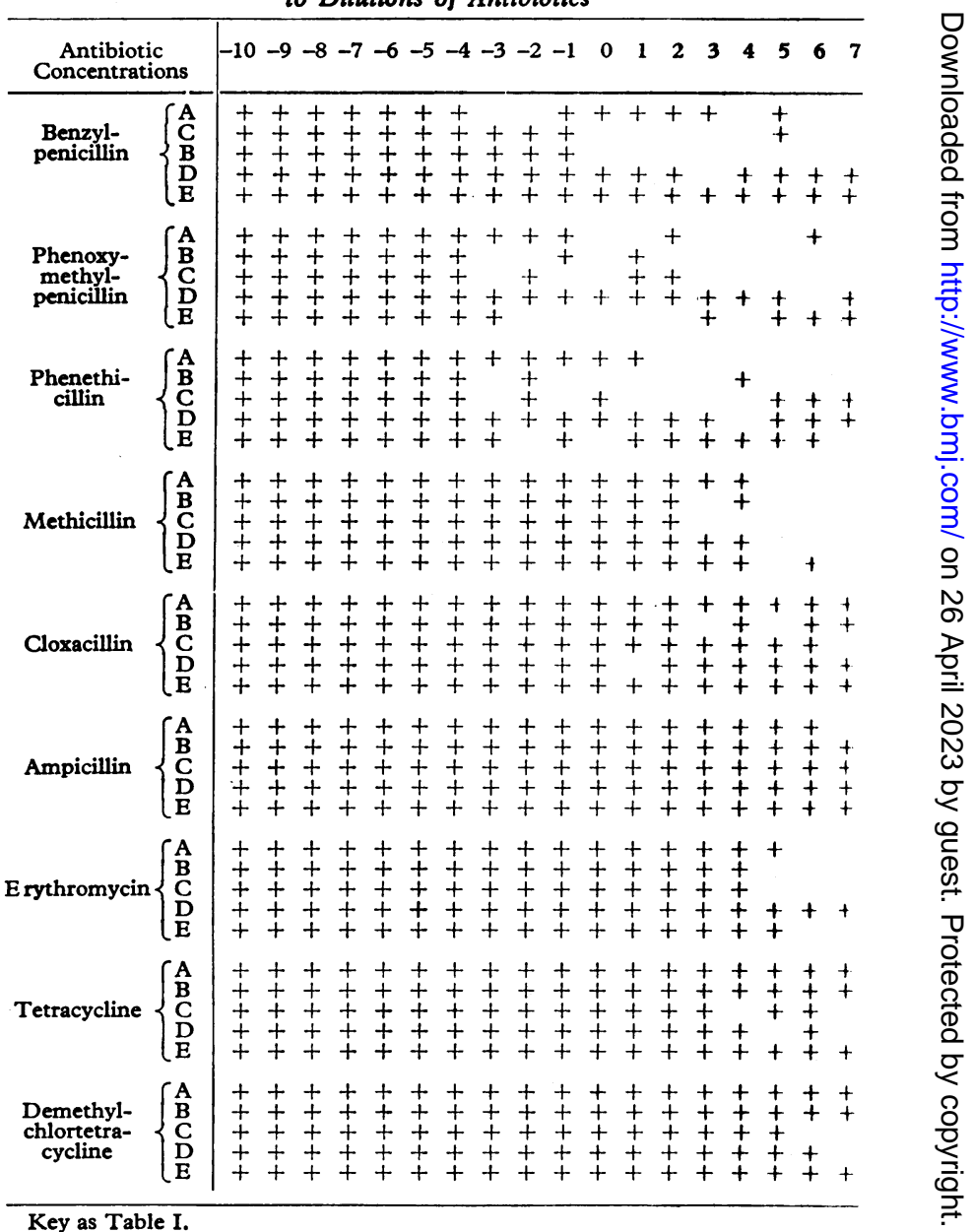

The concentrations are expressed on a $\log _{2}$ scale. + indicates some colonies The concentrations are expressed on a $\log _{2}$ scale. + indicates some colonies
remain viable. There is a reduction in the number of viable colonies in each tube as the concentration of antibiotic is increased. 
by the suspension method compared with previously published results may be due to the very small particle sizes in the suspension prepared by shaking with glass beads, and that the finer the suspension the more closely will the result approach the M.I.C. by the whole-colony method.

The apparent resistance of colonies to antibiotics has been shown to be solely a resistance to a bactericidal effect, and probably due to physical properties of the colony, into which it is difficult for the antibiotic to diffuse.

The importance of colony resistance to antibiotics in the treatment of patients remains, for in infection with $A$. israelii the organism is always found in colonial form. Although inhibition of colony growth can be obtained at very low levels of suitable antibiotics it is usually assumed that bactericidal levels of antibiotics are required for the successful treatment of actinomycosis. However, these in vitro experiments suggest that, at least for the strains examined, relatively low serum levels of the most effective antibiotics, if sustained for a sufficiently long period, will eradicate the infection.

The in vitro results confirm benzylpenicillin as the antibiotic of choice, but the organism is also shown to be very sensitive to phenoxymethylpenicillin, phenethicillin, and erythromycin.

No evidence has been found of the variation of inhibitory concentrations of antibiotic with different strains of actinomyces, which has been found by other authors (Strauss et al., 1951). There is a noticeable constancy in the results found for all the strains throughout the series of experiments, confirming in this respect the results of Suter and Vaughan (1955). The number of strains tested in this series is small, and other strains of different antibiotic sensitivities may well exist. However, the variations in previously reported results may also be due to the use of inocula containing particles of different sizes. Such variations in particle size would arise from the use of different methods for the preparation of suspensions of the organism and would affect the results obtained.

\section{Summary}

Minimum inhibitory concentrations of benzylpenicillin, phenoxymethylpenicillin, phenethicillin, méthicillin, cloxacillin, ampicillin, erythromycin, tetracycline, and demethylchlortetracycline against five strains of $A$. israelii from cervico-facial actinomycosis have been determined for whole colonies and for suspensions. The resistance of the colonies to antibiotics has been shown to be solely a resistance to bactericidal effect. No evidence of strain variation to the bacteriostatic effect of antibiotics has been found.

The assistance of Miss Joan Shepherd, senior technician in the bacteriology department, Eastman Dental Hospital, who carried out all the laboratory work for this investigation, is gratefully acknowledged. Messrs. Beecham Research Laboratories Ltd., Lederle Laboratories, Eli Lilly \& Co. Ltd., and Pfizer Ltd. supplied the antibiotics used in these experiments.

\section{REFERENCES}

Garrod, L. P. (1952). Brit. med. F., 1, 1263.

and Scowen, E. F. (1960). Brit. med. Bull., 16, 23

Holm, P. (1948). Acta path. microbiol. scand., 25, 376.

Strauss, R. E., Kligman, A. M., and Pillsbury, D. M. (1951). Amer. rev. Tuberc., 63, 441.

Suter, L. S., and Vaughan, B. F. (1955). Antibiot. and Chemother., 5, 557.

\title{
Comparison of Ampicillin and Chloramphenicol in Treatment of Paratyphoid Fever*
}

\author{
R. A. SLEET, $†$ M.B., CH.B., G. SANGSTER, $\ddagger$ M.D. ; J. MCC. MURDOCH,§ F.R.C.P.ED., M.R.C.P.GLASG.
}

Brit. med.f., 1964, 1, 148-150

Huckstep (1962) has reviewed and clarified the role of chloramphenicol in the treatment of the enteric fevers during the past ten years, but it has not been possible to evaluate the potential advantage of ampicillin over chloramphenicol, as no sufficiently large series has been reported. However, an opportunity to compare these antibiotics has been provided by the occurrence of a recent outbreak of paratyphoid fever in the Edinburgh area in which about 200 patients were involved. Salmonella paratyphi $B$-phage type Taunton-contaminating bakery products was primarily responsible for the outbreak, and details of the epidemiological aspects will be published elsewhere by others.

The in vitro activity and the high biliary concentration of ampicillin suggests that this penicillin is a suitable alternative to chloramphenicol. Successful results have been reported by Maddock (1962) in three patients with Salm. typhi infection and by Trafford et al. (1962) and Patel (1963) respectively in single patients, while Kennedy et al. (1963) obtained a satisfactory response in three patients although two required a second course with increased doses. In other salmonella infections results have been variable (Stewart et al., 1961 ; Ross

- From the City Hospital, Edinburgh.

+ Medical Registrar. $¥$ Physician. $\$$ Consultant Physician. et al., 1962 ; Tynes and Utz, 1962), but previous experience in this unit with Salm. paratyphi infections was favourable enough to warrant an extended trial. Two acutely ill patients and two of four carriers responded well, all but one having had chloramphenicol previously. The two failures were treated for three and four weeks with $3 \mathrm{~g}$. and $2 \mathrm{~g}$. daily respectively (Kennedy et al., 1963). Direct comparison with previously employed dose regimens was not possible as the duration of treatment varied and ampicillin dosage was between 50 and $200 \mathrm{mg} . / \mathrm{kg}$./day. Because of this it was decided to employ much higher doses of ampicillin, as previous work had suggested that they were more effective.

\section{Material and Methods}

Most of the patients were acutely ill in the earlier stages of the outbreak, and later, as might have been expected, more carriers were treated. The clinical picture showed the usual variation-from no symptomatology to typical paratyphoid fever.

Patients were admitted to the trial only when the diagnosis was confirmed either by bacteriological proof from blood or faeces or by a positive Widal reaction supported by 